\title{
SOCIO-ECONOMIC IMPACTS OF WATER SCARCITY IN DAR ES SALAAM, TANZANIA
}

\author{
Shadrack Mwakalila \\ Department of Geography \\ University of Dar es Salaam \\ P. O. Box 35049, Dar es Salaam, Tanzania \\ Email: smwakalila@yahoo.com
}

\begin{abstract}
Drought and the resulting low water levels in rivers exacerbate water scarcity conditions in Dar es Salaam city. The result is frequent water rationing in areas served with piped water, sometimes for days or weeks, and low water pressure, which leads residents to resort to other less safe and sometimes more expensive water sources. The frequent and current response to the inadequate piped water supply in Dar es Salaam has been the use of groundwater resources. There are both public and private bore-holes and wells drilling companies in Dar es Salaam.. This paper therefore, presents some socio-economic impacts of water scarcity in Dar es Salaam city. The methodology employed in field data and information collection includes interviews, questionnaire, focus group discussions and participatory observation. This is data triangulation, an essential technique for improving the reliability of data and information. The study reveals that the participation of local community (including water vendors and private business entrepreneurs) in water delivery systems through drilling bore-holes and shallow wells has improved water supplies in the study areas. However, the study has revealed some problems related to water scarcity in Dar es Salaam. These include high prices for water, poor sanitation and hygiene, unsafe and unclean water and inconvenient payment systems. Poor sanitation is related to stagnant water around the bore-holes and shallow wells. It is noted that unsafe water is mainly a problem for those obtaining water from water vendors and/or hire young men to collect water for household uses. However, the study concludes that individual's participation in water delivery systems in Dar es Salaam City has positively improved the life standards of the local people, particularly the poor.
\end{abstract}

Keywords: Dar es Salaam, Shallow wells, Water scarcity, Water vendors.

\section{INTRODUCTION}

Water is important for all life. It is used for drinking, washing, irrigated agriculture, generating hydro-electricity and for industrial processing. Water is also essential to support the earth's ecosystems. The aquatic ecosystems are important to people because they provide goods like Fisheries, floodplain grazing land, timber, reeds, medicine, and wildlife. The ecosystem services provided might be storage of rains within the undisturbed catchments, thus ensuring year-round river flow and moderate-sized floods (flood protection); good bank stability brought about by a complex community of riparian trees, and thus low sediment loads in the river; and very high recreational values due to the National Parks type setting and water quality improvement. Many people also depend directly on the natural resources and services of aquatic ecosystems. Among the costs of this system are that the land and water are not in use for agricultural or industrial production, and water may not be assured for any off-stream users during dry periods because flow has not been dammed and stored.

As water is an essential resource for life, it is alarming that a 1.1 billion people (18\% in 2000) of the world's people do not receive water on a daily and adequate supply (Seidenstar 2003). A related phenomenon is the 2.4 billion people ( $40 \%$ off the wold's population) that are not served by sanitation systems (Seidenstar 2003). The majority of the same population also tends to live in the nations defined as low-income by the World Bank, meaning they do not have adequate monetary resources to invest in high infrastructure investment and maintenance costs for water management. Tanzania is one of these countries.

Frameworks of water management institutions today, including greater private sector participation, are generally evolving to respond to water provisioning challenges experienced globally. Problems of water supply and quality rare on the increase due to the effect of rapid population growth, with $20 \%$ growth within the next 15 years (6.055 billion in 2000) to 7.105 billion in 2015) coupled with expanding spatial development (i.e settlement) in urban areas, which is often accompanied by land and water degradation. Equally challenging is the water provisioning process, fraught with high infrastructure costs dependent on economies that are presently declining and experiencing increased rates in poverty and 
unemployment. As resource with oftenunpredictability, but life is essential, more people are realizing the negative consequences resulting from poor, wasteful, or even absent management of water.

Drought and the resulting low water levels in Ruvu river exacerbate water scarcity conditions in Dar es Salaam. The result is frequent water rationing in areas saved with piped water, sometimes for days or weeks, and low water pressure, which leads residents to resort to other less safe and sometimes more expensive water sources. The frequent and current response to the inadequate piped water supply in Dar es Salaam has been the use of groundwater resources. There are both public and private bore-holes and wells drilling companies in Dar es Salaam.

The supply of water as a public utility by the state authority experiences acute problem of inadequate investment, under recovery of costs and unreliable water supplies particularly due to dependency on one source that is surface water which is determined by rainfall availability. The under investment in water supply and its consequences raised a great concern for the welfare of the people and economic development in Tanzania. Therefore, the solution was sought to increase private sector investment in water supplies. However, this still remains a problem because the privatized firms operate on the basis of cost recovery strategy and profit maximization. Thus, water become overpriced and the poor are more marginalized because of their low income. Apart from privatizing public water supply systems, there has been increase of ground water supply systems from bore-holes and shallow wells owned by local residents.

\section{THE STUDY AREA}

The Dare es Salaam region is situated in the eastern part of Tanzania Mainland. Dar es Salaam region is found between latitudes $6^{\circ} 40^{\prime}$ and $7^{\circ} 05^{\prime}$ South of the equator and longitudes $39^{\circ} 00^{\prime}$ and $39^{\circ} 35^{\prime}$ east of Greenwich. Dar es Salaam region borders Indian Ocean in the east and Coast region in the north, south and west. Major districts which make up Dar es Salaam region are: Kinondoni, Ilala and Temeke district.

Most of areas, especially those close to the City centre are supplied with piped water. Most of these systems were constructed during the colonial rule and currently are not functioning properly. The supply of piped water by Dar es Salaam Water
Sewerage and Sanitation (DAWASA) met only $45 \%$ of the total water demands (URT, 2004). In this case, those areas (wards and streets) located far from the City centre have no piped water supply. The main water sources in the study areas are bore-holes, shallow wells, rain water and water vendors. Other minor sources are piped water and natural water sources, such as Ruvu river. The study areas are not well endowed with surface water sources hence few people rely on streams. There are seasonal streams which are used for vegetable irrigation and livestock watering, but not for domestic uses because of perceived water pollution. Although groundwater resources are not well developed in Dar es Salaam City (Mato, 2002) and also poorly monitored in regard to its availability, bore-holes and shallow wells play a vital role in water supply in the study areas. This study therefore, addresses some socioeconomic impacts of water scarcity in Dar es Salaam, with special reference to Kinondoni and Ilala districts.

\section{METHODOLOGY}

\section{Methods of Data Collection}

The sampling frame for this study comprised wards and streets in Kinondoni and Ilala districts, Dar es Salaam region. The district was categorized into three major zones based on water supply systems, namely areas without public water delivery systems and boreholes, those with boreholes as the main water supply systems, and those with both public and boreholes as main water supply systems. Three wards were selected for the study namely Ubungo, Kitunda and Segerea wards. The study was conducted in 2006. The methods employed in field data and information collection include interviews, questionnaire, focus group discussions and participatory observation. This is data triangulation, an essential technique for improving the reliability of data and information.

\section{Focus Group Discussion}

A small group about five to ten people led by a researcher formed a discussion group. A focus group represent a cross section of water users and their institutions. These include, district, ward and street officials, individuals owning water supply systems, individuals utilising water for different uses, groups and institutions, which utilise water from the existing water supply systems. Three focus group discussions were organised one in each study street.

Focus group discussions are aimed at validating data and information gathered through other 
research instruments and clarifying controversial issues raised during the interview sessions (Jackson and Ingles, 1998; PRA handbook, 1991). The technique is also useful to investigate phenomena that cannot be obtained through direct observation such as individual opinions and attitudes (Kitchin and Tate, 1999).

\section{Participatory observation}

Under this method the researcher accompanied selected participants as they carry out their daily responsibilities related to water use and management, particularly during collecting water from different sources. The technique enabled the researcher to gain on the spot observation and understanding of the constraints and opportunities for water resource uses at household and community levels. Direct observation was made on water supply systems and how they operate and managed; distance walked to collect water, vessels and modes of carrying water, and modes of paying for water. Direct observation was a continuous process throughout the research period to enable a researcher to gain knowledge and record any differences and changes in water use and management. Direct observation is particularly important because sometimes data and information obtained through other methods may not correspond to what is actually seen in the field. Thus, by comparing results from direct observation and data and information collected through other research techniques and different sources, additional questions can be asked to fill any gaps in knowledge of the research topic under study (Flick, 1998; Jackson and Ingles, 1998). This increases the accuracy and reliability of the data and information collected.

\section{Interviews and Questionnaires}

Questionnaires were undertaken based on a stratified random sample from different groups of stakeholders. The groups from which the sample was drawn include ward and street officials, institutions operating water supply systems, individuals owning water supply systems, water vendors and other individual users of water. Furthermore, the stratification considered gender issues. The size of the sample population interviewed depended on the size and degree of variations of the population in each group (Babbie, 1983).

\section{Data Analysis and Presentation}

Data analysis was done using both quantitative and qualitative methods. SPSS and excel was used to analyze all the information that was collected quantitatively. Every response in every questionnaire was entered in the computer and the data analyzed to form statistics which were presented in frequency tables and figures. As for qualitative information, it was coded and analyzed using spread sheets and common responses. However, all the information was married with the observation observed during the research time.

\section{RESULTS AND DISCUSSION}

\section{Sample characteristics}

\section{Respondents by Wards and sex}

A total of 99 households were involved in this study, 52 households in Ubungo, 26 households in Tabata and 21 households in Segerea ward (Table 1). One person from each household was interviewed/participated in focus group discussion. Majority of the respondents were women (Table 2) because in the study areas women are responsible to take care for domestic water supplies, the main water use in the study areas. Women were therefore met either at home or at the water sources, such as boreholes, shallow wells and public standpipes.

Table 1: Respondents by Ward:

\begin{tabular}{|c|c|c|c|c|}
\hline Ward & Frequency & Percent & Valid Percent & Cumulative Percent \\
\hline Ubungo & 52 & 52.5 & 52.5 & 52.5 \\
\hline Tabata & 26 & 26.3 & 26.3 & 78.8 \\
\hline Segerea & 21 & 21.2 & 21.2 & 99.0 \\
\hline Total & 99 & 100 & 100 & \\
\hline
\end{tabular}


Table 2: Respondents by sex

\begin{tabular}{|c|c|c|c|}
\hline \multirow{2}{*}{ Ward } & \multicolumn{2}{|c|}{ Sex of the respondent } & Total \\
\cline { 2 - 4 } & Male & Female & \\
\hline Ubungo & 15 & 23 & 38 \\
\hline Tabata & 9 & 23 & 32 \\
\hline Segerea & 4 & 25 & 29 \\
\hline Total: & 28 & 71 & 99 \\
\hline
\end{tabular}

\section{Household size of the respondents}

Slightly less than half $(47 \%)$ of the households of the respondents have family size of between $5-8$ members (Table 3). Others have less than 5
(41.4\%); between 9-12 (10.1\%) and more than 12 $(1.0 \%)$.

Table 3: Household size of the respondents

\begin{tabular}{|l|l|l|l|l|}
\hline Household size & Frequency & Percent & Valid Percent & $\begin{array}{l}\text { Cumulative } \\
\text { Percent }\end{array}$ \\
\hline below 5 & 41 & 41.4 & 41.4 & 41.4 \\
\hline $5-8$ & 47 & 47.5 & 47.5 & 88.9 \\
\hline $9-12$ & 10 & 10.1 & 10.1 & 99.0 \\
\hline more than 12 & 1 & 1.0 & 1.0 & 100 \\
\hline Total & 99 & 100 & 100 & \\
\hline
\end{tabular}

\section{Education level of the respondents}

On the other hand, $18.2 \%$ of the respondents have attained primary education, $34.3 \%$ secondary education and $7.1 \%, 30.3 \%, 6.1 \%, 1.0 \%$ and $3.0 \%$ are Vocational Education and Training (VETA), Diploma, Religious respectively and those not attended formal education respectively (Table 4).

Table 4: Education level of the respondents

\begin{tabular}{|l|l|l|l|l|}
\hline Level of Education & Frequency & Percent & Valid Percent & $\begin{array}{l}\text { Cumulative } \\
\text { Percent }\end{array}$ \\
\hline Primary & 18 & 18.2 & 18.2 & 18.2 \\
\hline Secondary & 34 & 34.3 & 34.3 & 52.5 \\
\hline VETA & 7 & 7.1 & 7.1 & 59.6 \\
\hline Diploma & 30 & 30.3 & 30.3 & 89.9 \\
\hline University & 6 & 6.1 & 6.1 & 96.0 \\
\hline Religious & 1 & 1.0 & 1.0 & 97.0 \\
\hline No Education & 3 & 3.0 & 3.0 & 100 \\
\hline Total & 99 & 100 & 100 & \\
\hline
\end{tabular}

Involvement of water vendors in water delivery systems

The involvement of water vendors in water delivery systems in the study areas has some significant impacts to the water users. The impacts include saving and reducing time spent to fetch water, save and reduce money spent to obtain water, getting safe and clean water and being sure of adequacy of water supply for the household uses. Others are such as increased construction activities and town expansion (Table 5). 
Table 5 Responses on the impact of water vendors in water delivery systems

\begin{tabular}{|l|l|l|l|l|}
\hline & Frequency & Percent & Valid Percent & $\begin{array}{l}\text { Cumulative } \\
\text { Percent }\end{array}$ \\
\hline Save and reduce time spent to fetch water & 89 & 89.9 & 89.9 & 89.9 \\
\hline Save and reduce money spent to obtain water & 6 & 6.1 & 6.1 & 96.0 \\
\hline Get safe and clean & 1 & 1.0 & 1.0 & 97.0 \\
\hline $\begin{array}{l}\text { Being sure of adequacy of water for the } \\
\text { household uses }\end{array}$ & 1 & 1.0 & 1.0 & 98.0 \\
\hline $\begin{array}{l}\text { Increased construction activities and town } \\
\text { expansion }\end{array}$ & 1 & 1.0 & 1.0 & 99.0 \\
\hline *All & 1 & 1.0 & 1.0 & 100 \\
\hline Total & 99 & 100 & 100 & \\
\hline
\end{tabular}

*'All' indicates that respondents mentioned all factors (save time and money, get safe and clean water, assurance of water supply and increased construction activities and town expansion.

Although acknowledging that participation of water vendors in water delivery systems has improved water supplies in the study areas, water users revealed some problems related to individual water delivery systems. These include high prices for water, poor sanitation and hygiene, unsafe and unclean water and inconvenient payment systems (Table 6). Poor sanitation is related to stagnant water around the bore-holes and shallow wells. It was noted that unsafe water is mainly a problem for those obtaining water from water vendors and/or hire young men to collect water for household uses.

Table 6. Major problems associated with water scarcity

\begin{tabular}{|c|c|c|c|c|}
\hline Major problems & Frequency & Percent & Valid Percent & $\begin{array}{l}\text { Cumulative } \\
\text { Percent }\end{array}$ \\
\hline High price of water & 12 & 12.1 & 12.1 & 12.1 \\
\hline Poor sanitation services & 29 & 29.3 & 29.3 & 41.4 \\
\hline Use of stagnant water & 1 & 1.0 & 1.0 & 42.4 \\
\hline Poor hygiene of water & 15 & 15.2 & 15.2 & 57.6 \\
\hline Unsafe water & 42 & 42.4 & 42.4 & 100 \\
\hline Total & 99 & 100 & 100 & \\
\hline
\end{tabular}

Majority of the households in the study areas are neither connected to piped water nor have access to public standpipes. Thus, most of them have to pay for water except for rainwater. Those owning water sources, particularly bore-holes and shallow wells reported high initial costs, which make the majority of the households unable to drill bore-holes and shallow wells, hence rely on buying water from their neighbours. Average household expenditures on water per month are presented in Table 7.

Table 7: Average expenditure per month for water use

\begin{tabular}{|l|l|l|l|l|}
\hline *Expenditure (Tshs) & Frequency & Percent & Valid Percent & Cumulative Percent \\
\hline below10,000 & 2 & 2.0 & 2.0 & 2.0 \\
\hline $10,000-20,000$ & 1 & 1.0 & 1.0 & 3.0 \\
\hline $20,001-30,000$ & 8 & 8.1 & 8.1 & 11.1 \\
\hline $30,001-40,000$ & 28 & 28.3 & 28.3 & 39.4 \\
\hline $40.001-50,000$ & 27 & 27.3 & 27.3 & 66.7 \\
\hline above 50,000 & 33 & 33.3 & 33.3 & 100 \\
\hline Total & 99 & 100 & 100 & \\
\hline
\end{tabular}

*Exchange rate in 2006: 1USD $=1350$ Tshs

Household water uses determine the amount of water the household needs for a particular place and time. The main water uses in the study areas are domestic, irrigation and livestock. Irrigation is mainly for vegetables, which are grown for commercial purposes. The main types of livestock in the study areas include poultry, pigs and cattle. 
The amount of water used for various purposes per day is more than 100 litres.

Distance to nearest water source and implications

The amount of water the household use and the amount of money spent to obtain water is greatly influenced by the distance from the household to the nearest water source (Table 8). Members of the household tend to collect water themselves when the distance to the nearest water source is short while they hire young men to collect water when the distance to the nearest water source is long. The implication for this is that when collecting water direct from a water source the price per one-20-litres bucket is only 20 Tanzanian shillings while when hiring a person the minimum price is 120 Tanzanian shillings.

Table 8(a): Responses on the distance to the nearest water source 5 years ago

\begin{tabular}{|l|l|l|l|l|}
\hline & Frequency & Percent & $\begin{array}{l}\text { Valid } \\
\text { Percent }\end{array}$ & $\begin{array}{l}\text { Cumulative } \\
\text { Percent }\end{array}$ \\
\hline within $200 \mathrm{~m}$ & 57 & 57.6 & 57.6 & 57.6 \\
\hline $201-400 \mathrm{~m}$ & 30 & 30.3 & 30.3 & 87.9 \\
\hline $401-600 \mathrm{~m}$ & 5 & 5.1 & 5.1 & 92.9 \\
\hline $601-800 \mathrm{~m}$ & 2 & 2.0 & 2.0 & 94.9 \\
\hline $801-1000 \mathrm{~m}$ & 3 & 3.0 & 3.0 & 98.0 \\
\hline over $1000 \mathrm{~m}$ & 2 & 2.0 & 2.0 & 100 \\
\hline Total & 99 & 100 & 100 & \\
\hline
\end{tabular}

Table 8(b): Responses on the distance to the nearest water source at present

\begin{tabular}{|l|l|l|l|l|}
\hline & Frequency & Percent & $\begin{array}{l}\text { Valid } \\
\text { Percent }\end{array}$ & $\begin{array}{l}\text { Cumulative } \\
\text { Percent }\end{array}$ \\
\hline withince $200 \mathrm{~m}$ & 88 & 89.8 & 89.8 & 89.8 \\
\hline $201-400 \mathrm{~m}$ & 6 & 6.1 & 6.1 & 95.9 \\
\hline $401-600 \mathrm{~m}$ & 3 & 3.0 & 3.1 & 98.0 \\
\hline $801-1000 \mathrm{~m}$ & 1 & 1.0 & 1.0 & 99.0 \\
\hline over $1000 \mathrm{~m}$ & 1 & 1.0 & 1.0 & 100 \\
\hline Total & 99 & 100 & 100 & \\
\hline
\end{tabular}

Tables 8 above, indicate that currently there is a decrease of distances walked to the nearest water source from the respondents' homestead as compared to five years ago. At present about 90 percent of the respondents walk within $200 \mathrm{~m}$ to the nearest water source as compared to about 58 percent 5 years ago. This indicates that as more individuals are engaged in water delivery systems through drilling bore-holes and shallow wells local people have saved both time and money spend to collect water for household uses.

Quality of water from individual water delivery systems

Residents of Ubungo, Kitunda and Segerea wards in Dar es Salaam have different perceptions with regard to the quality of water. Generally, the quality of water is based on colour, particles and location of the water source. During the focus group discussions, it was noted that water from bore-holes is generally regarded as safe and clean water and most people use the water without any treatment. Water from sources located along the rivers, streams and near pit latrines are generally perceived as having poor quality regardless of the depth of the bore-holes and shallow wells. 30 percent of the respondents perceived water quality as good, 38 percent perceived water quality as moderate while 32 percent perceived water quality in the study areas as poor or worse (Figure 2). 


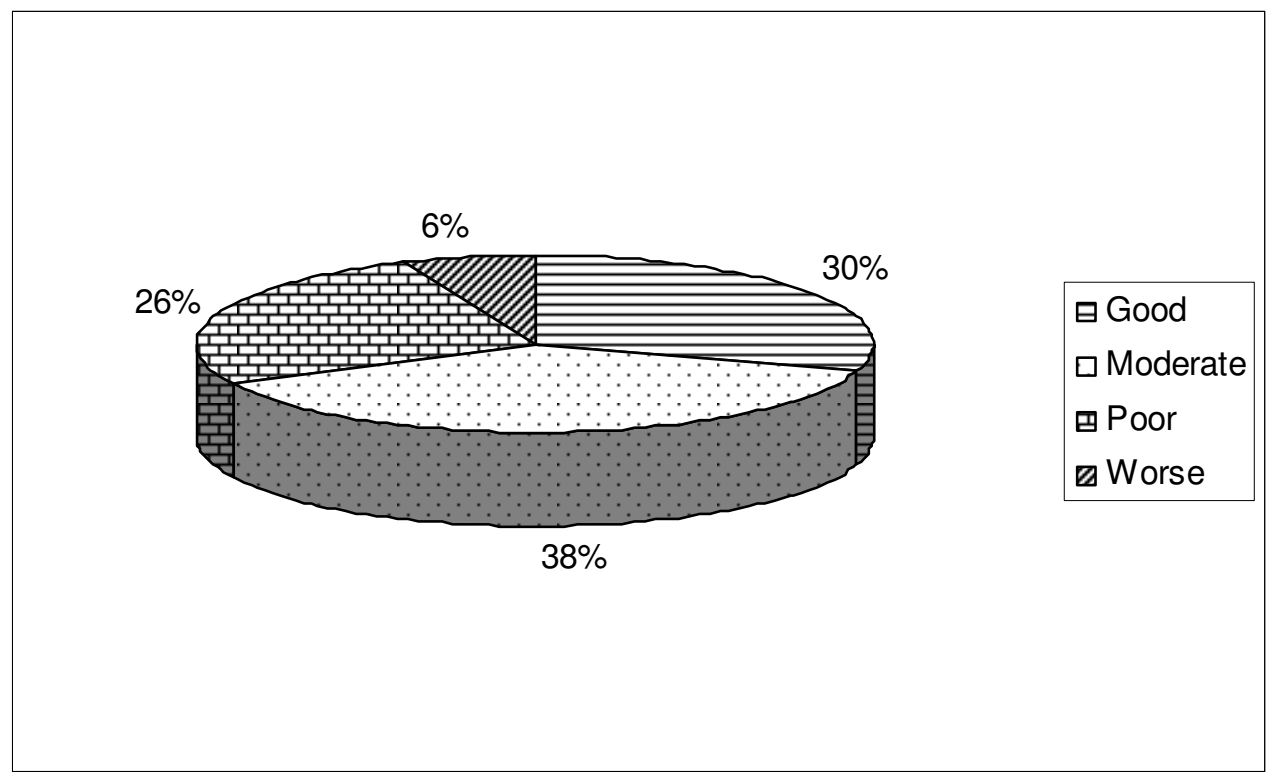

Figure 2: Responses on the perception about the level of water quality

\section{CONCLUSIONS}

The study reveals that the water vendors in Dar es Salaam have reduced time spent to obtain water. The reduced time is spent in other socio-economic activities hence improve the quality of living standard of the local people in the study areas. However, the study has revealed some socioeconomic problems related to water scarcity. These include high prices for water from water vendors, poor sanitation and hygiene, unsafe and unclean water and inconvenient payment systems. Poor sanitation is related to stagnant water around the bore-holes and shallow wells. It is noted that unsafe water is mainly a problem for those obtaining water from water vendors and/or hire young men to collect water for household uses.

\section{REFERENCES}

Babbie E., (1983) Practice of Social Research, Wadworth Publishing Company, Belmont, California.

Flick, U., (1998) An Introduction to Qualitative Research. Sage Publications, London

Jackson, W.J., and Ingeles, A.W., (1998) Participatory Techniques for community Forestry: A field manual: IUCN.
Kitchin, R., and Tate, N.J., (2000) Conducting Research into Human Geography, Theory, Methodology and Practice. Pearson Education Limited, England.

Mato, R., (2002) Groundwater Pollution in Urban Dar es Salaam, Tanzania: Assessing Vulnerability and Protection Priorities.University Press Eindhoven University of Technology

Participatory Rural Appraisal Handbook, (1991). Conducting PRAs in Kenya: World Resource Institute, Washington DC and Clark University Mass.

Seidenstat, P., (2003) Global Challenges to Providing Water and Waste Water Services. World Economics, Vol. 4(1).

United Republic of Tanzania, (2004) Tanzania Census, 2002 Population and Housing Census Volume IV. Districts Profiles, Dar es Salaam

Accessed on $18^{\text {th }}$ May 2005. 